\title{
Respondibilidade na Rede: a construção das fanarts de Sherlock
}

\author{
Marcela Barchi Paglione \\ Universidade Estadual Paulista "Júlio de Mesquita Filho" (UNESP), \\ Araraquara, São Paulo, Brasil \\ marcelapaglione@gmail.com
}

DOI: http://dx.doi.org/10.21165/el.v46i3.1591

\begin{abstract}
Resumo
Este trabalho se propõe a analisar o estilo nas fanarts, imagens produzidas por fãs, especificamente os do seriado televisivo Sherlock (2010), sob a perspectiva dos estudos do Círculo Bakhtin, Medviédev, Volochínov (BMV). Parte da recepção-ativa do seriado, as fanarts têm sua respondibilidade tão aguçada que re-produzem a obra que as gerou, em um movimento dialético-dialógico (PAULA et ali, 2011) vivo. O objetivo deste artigo é o de identificação dos elementos de produção que remetem ao estilo dos autores, a fim de ressaltar a característica responsiva dos enunciados dos fãs (BAKHTIN, 2011), considerados como um processo de circulação, produção e recepção (trans)midiática de Sherlock, na Rede. Assim, acredita-se ser possível compreender em que medida as fanarts analisadas são respostas ao seriado e como tais enunciados, por sua vez, influenciam a sua constituição e o seu estilo.
\end{abstract}

Palavras-chave: estilo; Bakhtin; seriado televisivo.

\section{Responsible-answerability on the Net: the construction of Sherlock fanarts}

\begin{abstract}
This paper proposes to analyze the style in fanarts, the images produced by fans, specifically the ones from the Sherlock (2010) TV show, under the perspective of the Bakhtin, Medvíedev and Volochinov Circle. As a part of the active-reception of the TV series, the fanarts have a so keen responsible-answerability that they re-produce the work that generated them, in a dialecticdialogical alive movement (PAULA et ali, 2011). Our objective is to identify the elements of production which refer to the authors' styles to emphasize the responsive characteristics of the fans' utterances (BAKHTIN, 2011), considered as a process of (trans) media circulation, production and reception of Sherlock, on the Net. Therefore, we believe it is possible to understand in what extent the analyzed fanarts are a response to the TV series and how theses utterances, on their turn, influence its constitution and its style.
\end{abstract}

Keywords: style; Bakhtin; TV series.

\section{Introdução}

$\mathrm{Na}$ contemporaneidade, percebemos uma modificação na recepção do seriado a fim de atender às necessidades de um público mais interativo, conforme as tendências implementadas pela revolução tecnológica e, com ela, o avanço da internet no que consideramos como mídias digitais (conforme LÉVY, 2008 e MORAES, 2001).

Coincidentemente com essa ideologia participativa, o seriado caminha em uma direção cada vez mais digital ao disponibilizar conteúdo online, transmidiaticamente (JENKINS, 2006), como aplicativos para smartphones, trailers interativos, entre outros, e passa a prever a recepção dos fãs em Rede, em sites como Tumblr, Devianart, 
Fanfiction.net, em diversas materialidades, como parte de sua constituição, também considerada como transmidiática.

Nesse sentido, entendemos a recepção dos fãs que tomará forma de fanfics, fanarts, fanvideos, fanedits, gifs, cosplays, etc. como produção autoral na qual instauramse marcas estilísticas dos sujeitos autores, uma vez que, segundo Discini (2010, p. 115), estilo "[...] é a recorrência de um modo de dizer que remete a um modo de ser".

Utilizamos como base para a análise os estudos da linguagem do Círculo Bakhtin, Medvíedev, Volochinov (BMV) ${ }^{1}$, centrados na natureza dialógica da linguagem. Nesse sentido, os enunciados dos fãs são responsivos em relação ao seriado (BAKHTIN, 2011) e podem ser considerados como produção justamente por sua característica de respondibilidade, pois, para o Círculo, nenhum enunciado é exatamente original, ele sempre se instala em uma cadeia de enunciados aos quais responde, seja em memória de passado ou de futuro. Trabalhamos com a ideia de que o seriado televisivo é um gênero discursivo (BAKHTIN, 2011; MEDVÍEDEV, 2012), como discorreremos ao longo do trabalho, e, como tal, não deve ser analisado fora de sua movimentação social.

A partir do seriado televisivo Sherlock (2010), o qual conta com uma recriação do detetive Sherlock Holmes ambientado no século XXI, observamos como seus fãs respondem a essa produção e criam, por sua vez, enunciados autorais, disponibilizados na Rede. A partir da relação responsável entre produção (com forma, conteúdo e estilo), circulação e recepção social, é possível estabelecermos a arquitetônica do seriado. Neste trabalho, como um recorte de nossa pesquisa de doutorado intitulada "Fenômeno Sherlock: a recepção social do gênero seriado"2, centrar-nos-emos na análise de suas fanarts e veremos como é estabelecido o estilo das produções dos fãs, que as individualiza ao mesmo tempo em que as insere em um grupo.

Na contemporaneidade, faz-se necessário um estudo sobre as modificações dos gêneros. Entre eles, o seriado televisivo ganha destaque por sua ampla circulação social, primeiramente em relação a um público jovem e, posteriormente, expandido para diversos setores da sociedade, em uma preocupação massiva de angariar o público com maior número e mais diversidade possível. Procuramos, assim, contribuir para os estudos dos gêneros discursivos em sua conformidade com as produções contemporâneas, especialmente a partir das mídias digitais.

\section{A constituição (trans)midiática do gênero seriado}

A partir dos estudos do Círculo, que evidenciam uma dimensão dialógica, ética e estética da linguagem, tomamos como base as obras Estética da criação verbal (BAKHTIN, 2011) e O método formal nos estudos literários (MEDVÍEDEV, 2012), principalmente, a fim de embasarmos nossa discussão acerca do gênero discursivo, dentro do qual pensamos o seriado.

Em um primeiro momento, pensar o gênero envolve sua constituição formal, nunca dissociado de seu conteúdo, no qual, para Medvíedev (2012), estão refratados os

\footnotetext{
${ }^{1}$ Adotamos a nomenclatura utilizada por Vauthier (2010), ao invés do comumente conhecido "Círculo de Bakhtin" para uma tentativa de defesa da autoria dos outros membros do Círculo.

2 Pesquisa financiada pela Fundação de Amparo à Pesquisa do Estado de São Paulo (FAPESP), processo $n^{\circ} 2017 / 04260-8$.
} 
valores da sociedade em que se realiza o enunciado. De maneira conjunta, ele também envolve a questão estilística, com características específicas de formulação pertencentes tanto ao gênero em questão, quanto ao sujeito que assume a voz de enunciador e ali imprime sua marca.

Todas essas instâncias estão interligadas, em uma relação responsiva e responsável, uma vez que a organização formal jamais pode ser dissociada de um conteúdo temático (consequentemente dos valores sociais que veicula) e vice-versa, sempre escolhidas a partir do tom-emotivo volitivo de um determinado sujeito, em uma relação espaço-temporal específica, sem jamais deixarmos de lado, porém, que qualquer determinação é temporária.

Nesse sentido, ao pensarmos o seriado televisivo, devemos considerar suas regularidades marcadas pelo elemento proeminente de uma narrativa entrecortada em episódios, o que lhe permite sua caracterização enquanto um produto em série, agrupados em uma temporada, os quais podem ser mais ou menos interdependentes, a depender, por exemplo, de ser um seriado dramático, especialmente os policiais, em que há maior continuidade da narrativa a fim de culminar em um clímax ao final da temporada. Ao contrário, um seriado de comédia, principalmente sitcoms (comédias de situação), oferece maior possibilidade de assistir aos episódios de maneira independente. Há a escolha, por exemplo, do tempo do episódio: 20, 40, ou 50 minutos, aproximadamente, a depender se se trata de uma obra dramática, mais longa, ou de comédia, mais curta, além de verificarmos se são produções americanas ou inglesas, sendo a primeira marcada por temporadas mais longas e episódios mais curtos, ao contrário da segunda.

Tais apontamentos de regularidades possíveis estão, no entanto, condicionados à movimentação do gênero em sociedade. Vemos estabelecer-se dentro de sua órbita um jogo entre instabilidade e estabilidade, entre forças centrípetas e centrífugas que cria relativa estabilidade, ora pendendo mais para um dos polos, ora para outro, mas jamais estagnando-se, pois, na medida em que o gênero está vivo em sociedade, ele está disposto à mudança. A partir do momento em que ele se fecha em uma única constituição, se afasta de seu uso por sujeitos sociais e torna-se qualquer coisa fora um gênero, como uma forma, marcada apenas pelo viés composicional. De acordo com Medvíedev (2012, p. 72),

Uma obra literária não pode ser compreendida fora da unidade da literatura. Mas essa unidade em seu todo, assim como cada um de seus elementos, não pode ser compreendida fora da unidade da vida ideológica. Por sua vez, essa unidade não pode ser estudada em sua totalidade, nem em seus elementos isolados, fora de uma única lei socioeconômica.

Em sua discussão com os formalistas, o autor (MEDVÍEDEV, 2012) defende o estudo da obra de arte como um enunciado ideológico, inserida em um determinado tempo-espaço, a partir da enunciação de um sujeito sócio histórico. A análise de sua forma, pura e simplesmente, não contempla a complexidade do jogo de forças sociais em embate ali refratados. Nesse sentido, em defesa de uma poética sociológica, é necessário inserirmos, ou melhor, jamais retirarmos a obra de suas condições reais de produção, circulação e recepção.

Com essas categorias de análise, procuramos dar conta da dimensão do movimento do gênero em uma esfera de atividade - no caso do seriado, midiática. Para Bakhtin (2011, p. 262), 
Os elementos dos tipos de enunciados, o tema, conteúdo e estilo, são "determinados pela especificidade de um determinado campo da comunicação. Evidentemente, cada enunciado particular é individual, mas cada campo de utilização da língua elabora seus tipos relativamente estáveis de enunciados".

Os tipos relativamente estáveis de enunciados, a saber, os gêneros discursivos, constituem-se a partir das necessidades comunicativas de uma dada esfera em que emergem, as quais estabelecem, pelo uso, os elementos recorrentes que caracterizam um gênero em um determinado espaço-tempo. A esfera, nesse sentido, "[...] é compreendida como um nível específico de coerções que, sem desconsiderar a influência da instância socioeconômica, constitui as produções ideológicas, segundo a lógica particular de cada esfera/campo" (GRILLO, 2006, p. 143). Suscetíveis, no entanto, à alteração, essas coerções determinam até certo ponto os enunciados, posto que são linguagem em chama viva, concreta e ideologicamente situados no diálogo entre sujeitos.

Originalmente, o seriado é produzido para circular na televisão, o que implica determinados interesses econômicos incutidos desde as primeiras etapas de sua produção, como a encomenda de um número específico de episódios por temporada; os interesses do canal em que será exibido; além da possibilidade de cancelamento caso não haja público.

Desde os anos 50, os seriados assumiam, principalmente na televisão norteamericana, o papel de entreter a população e de veículo de valores comuns a essa comunidade, como os do American way, por exemplo. Em um processo concomitante em relação à difusão e popularização dos televisores, os seriados tornam-se cada vez mais presentes na sociedade para, hoje, adquirirem o posto de um dos meios de entretenimento mais populares, principalmente entre os jovens.

$\mathrm{Na}$ contemporaneidade, por sua vez, as mídias digitais ganham foco e tornam-se cada vez mais presentes no funcionamento da sociedade. Segundo Moraes (2001), há um embate (ideológico) entre as mídias tradicionais, chamadas por ele como "de massa", e as mídias digitais. Enquanto no primeiro caso haveria a primazia da centralização da informação e negligenciamento das singularidades de um público em prol de um denominador comum, haveria no segundo a dissolução dos polos de "emissor" e "receptor", de maneira que as barreiras entre quem recebe e quem emite informações são desintegradas. Nesse sentido, há um efeito de liberdade e interatividade presente com a expansão das mídias digitais, culminando na constituição de um ciberespaço (LÉVY, 2008) em que todos podem assumir a voz de falantes e emitir informações, além de sempre serem passíveis de resposta.

Lévy (2008) também evidencia o jogo de forças centrípetas e centrífugas sobre a distribuição de informações nas mídias e estabelece a pretensão de uma distribuição de informações centralizada no caso das mídias tradicionais, em que haveria a propagação ideológica de um enunciado para um grande público (relação um-todos), o qual nunca tomará uma posição ativa de produtor de enunciados em um nível macro. Para as mídias digitais, entretanto, há uma relação todos-todos, conforme aponta Moraes (2001, p. 70):

A pragmática da Internet desfaz a polaridade entre um centro emissor ativo e receptores passivos. As interfaces tecnológicas instituem um espaço de transação, cujo suporte técnico, em processamento constante, proporciona comunicações intermitentes, precisas e ultrarrápidas, numa interação entre todos e todos, e não mais entre um e todos. 
Assim, na Rede, seria possível o estabelecimento de uma participação ativa dos sujeitos internautas, pois todos poderiam ter acesso e trocar informações. O seriado, como um gênero, mobiliza-se nessa esfera e recebe influências dessas digitais formas de interação, as quais veiculam principalmente valores de uma ideologia participativa, em contraponto às mídias tradicionais em que prevalece o polo mais centralizante da informação.

No entanto, tais constatações devem ser levadas ao questionamento, visto que os sujeitos e enunciados permanecem ideológicos e ainda perpassam fatores comerciais na esfera midiática, de modo que, a nosso ver, há um jogo de forças nas digitais mídias, ao mesmo tempo pendendo para a interatividade, porém sem deixar de estabelecer as relações massivas e econômicas decorrentes dessa estratégia.

Diante desse panorama, pensamos em uma possível reconstituição do gênero seriado a caminhar em direção a uma perspectiva interativa, com base na participação dos fãs: o seriado sai da televisão e espalha-se na Rede, de forma a possibilitar respostasativas do público.

A partir de uma premissa participativa, pensamos em uma arquitetônica responsiva do seriado, dentre os quais se destaca Sherlock (2010), no sentido de que a resposta-ativa do público, principalmente os fãs, é pensada e incentivada desde sua produção. Para tal, é utilizada a narrativa transmídia (JENKINS, 2006) em que uma narrativa se desdobra e cria novos nós em diversas mídias em prol do entretenimento como uma estratégia de promoção do seriado. Foram criados blogs do detetive e de John Watson; um trailer interativo para a terceira temporada, em que os fãs podem acessar conteúdos exclusivos ao clicarem em hotspots na tela; além de um aplicativo do seriado e páginas nas plataformas Facebook, Twitter e Youtube, por exemplo. Pensamos tais questões como medidas do seriado em direção ao público-fã, como uma estratégia para inseri-los em sua produção e torná-la, desse modo, mais interativa, possibilitado tanto pelo avanço da tecnologia quanto pela valoração positiva dada a um produto interativo.

Assistir ao seriado, no âmbito das mídias digitais, implica participar de sua constituição nas redes sociais, respondê-lo ativamente, e não mais somente assistir ao episódio "passivamente" - sabemos que, bakhtinianamente, qualquer medida de compreensão já é uma resposta do sujeito e este nunca é um elemento vazio em que são incutidos informações e valores, portanto, a denominação de uma atuação passiva do fã é dada em prol de um contraste com a constituição anterior do gênero seriado.

A arquitetônica responsiva do seriado e, em particular, de Sherlock, implica em um duplo movimento, midiático: se por um lado há os enunciados criados pela produção do seriado para sua repercussão na Rede, em um movimento em direção aos fãs, há também o movimento dos fãs em direção ao seriado, que também o constitui transmidiaticamente.

Os fãs respondem ativamente na Rede e são entendidos por nós como sujeitos em sua individualidade, motivo pelo qual passamos a denominá-los como tal, diferentemente de "público", vocábulo que assume uma conotação massiva. Em sua resposta, eles constroem enunciados em suas diversas materialidades, como fanarts, fanvideos, teorias em posts, entre outros.

Em contraponto à concepção de De Certeau (apud JENKINS, 1992) sobre a legitimidade dos enunciados "oficiais", os enunciados dos fãs são aqui considerados 
autorais. Eles são responsivos, conforme a concepção do enunciado para Bakhtin (2011), porém isso não diminui sua autenticidade, motivo pelo qual nos baseamos nessa teoria. Consideramos, assim, a recepção do seriado pelos fãs como também uma produção na qual há a marca enunciativa do sujeito que fala, compreendido em sua singularidade. Para tal, analisaremos agora de que maneira essas singularidades são construídas em fanarts de Sherlock.

\section{Fanarts e a compreensão do estilo nas produções dos fãs de seriado}

Consideramos Fanart, em sentido geral, como uma construção enunciativa típica da produção dos fãs, geralmente em formato de pintura, seja ela tradicional, com grafite e aquarela, por exemplo, como também em pintura digital. Esse tipo enunciativo não se resume a produções feitas exclusivamente por fãs de seriados, mas estende-se também aos de filmes, livros e animes, por exemplo, sempre ligado a um produto de distribuição massiva. Como já diz o nome (fan-art), trata-se de uma produção artística e autoral dos fãs, que procura responder ao enunciado canônico à sua maneira.

O fã tomado como sujeito - e não mais um mero receptor de informações veiculadas pelas mídias totalizantes - responde ao discurso "oficial" de seu interesse e, enquanto o faz, em sua compreensão-responsiva, imprime em sua produção o seu estilo. Segundo Discini (2010), o estilo pode ser compreendido como uma palavra - no sentido lato - legitimada pela atribuição desta feita pelos sujeitos. Assim, uma forma linguística assume um tom valorativo e deixa de ser mera forma de um sistema, vazia por si só, para tornar-se um elemento significativo de um enunciado a partir da voz do sujeito enunciado.

Para a autora (DISCINI, 2010, p. 130), "a língua se faz discurso na perspectiva de uma estilística discursiva. A seleção que o locutor efetua de uma forma gramatical é um ato estilístico; a seleção que o locutor efetua de um determinado gênero é um ato estilístico [...]". Assim, os enunciados dos fãs possuem a marca estilística dos sujeitos que o enunciam presente nos elementos da produção, seja na escolha do tipo de enunciado, na cor, na representação da personagem, etc. Cada escolha de um elemento implica um posicionamento do sujeito, ao mesmo tempo que exclui as outras materialidades possíveis para ali serem utilizadas, visto que se escolhe este e não aquele formato, em decorrência de sua relação com o conteúdo e suas implicações ideológicas.

Para Discini (2010, p. 116), “procurar obter da palavra do homem constitutivamente uno e duplo o modo peculiar de ser responsivo firma o estilo como fato diferencial". A partir da noção do sujeito único em seu local na existência e cindido na fronteira de sua relação com o outro, o estilo do fã, ao mesmo tempo em que instaura sua entonação valorativa (VOLOCHINOV, 1926), sua singularidade, também está construído em diálogo com o seriado e as outras produções fanmade.

Tais enunciados de fãs circulam em plataformas específicas na Rede, principalmente Tumblr e Devianart, as quais funcionam como comunidades virtuais (LÉVY, 2008) em que os fãs interagem, a partir de uma premissa colaborativa. Veremos a seguir alguns dos enunciados considerados como fanarts e que, no caso, orientam-se segundo uma temática emotiva decorrente da (falsa) morte de Sherlock, em The Reichenbach Fall (2012), no seriado. 


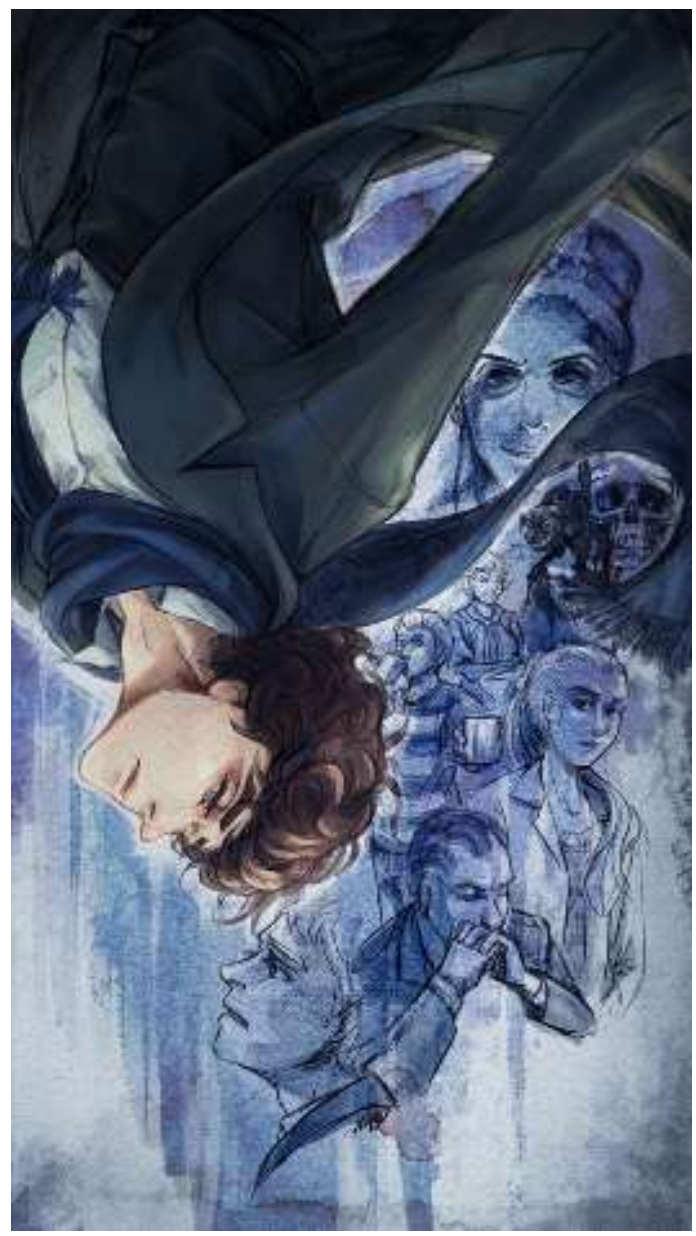

Figura 1. BBC SHERLOCK - Sherlock (2012)

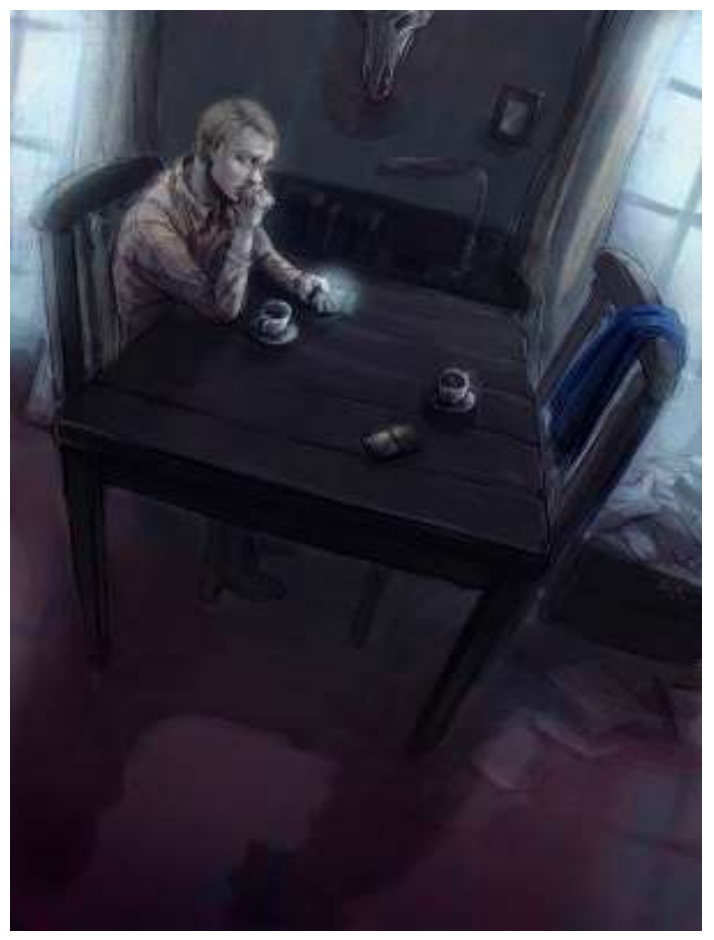

Figura 2. One more miracle, please (2012) 


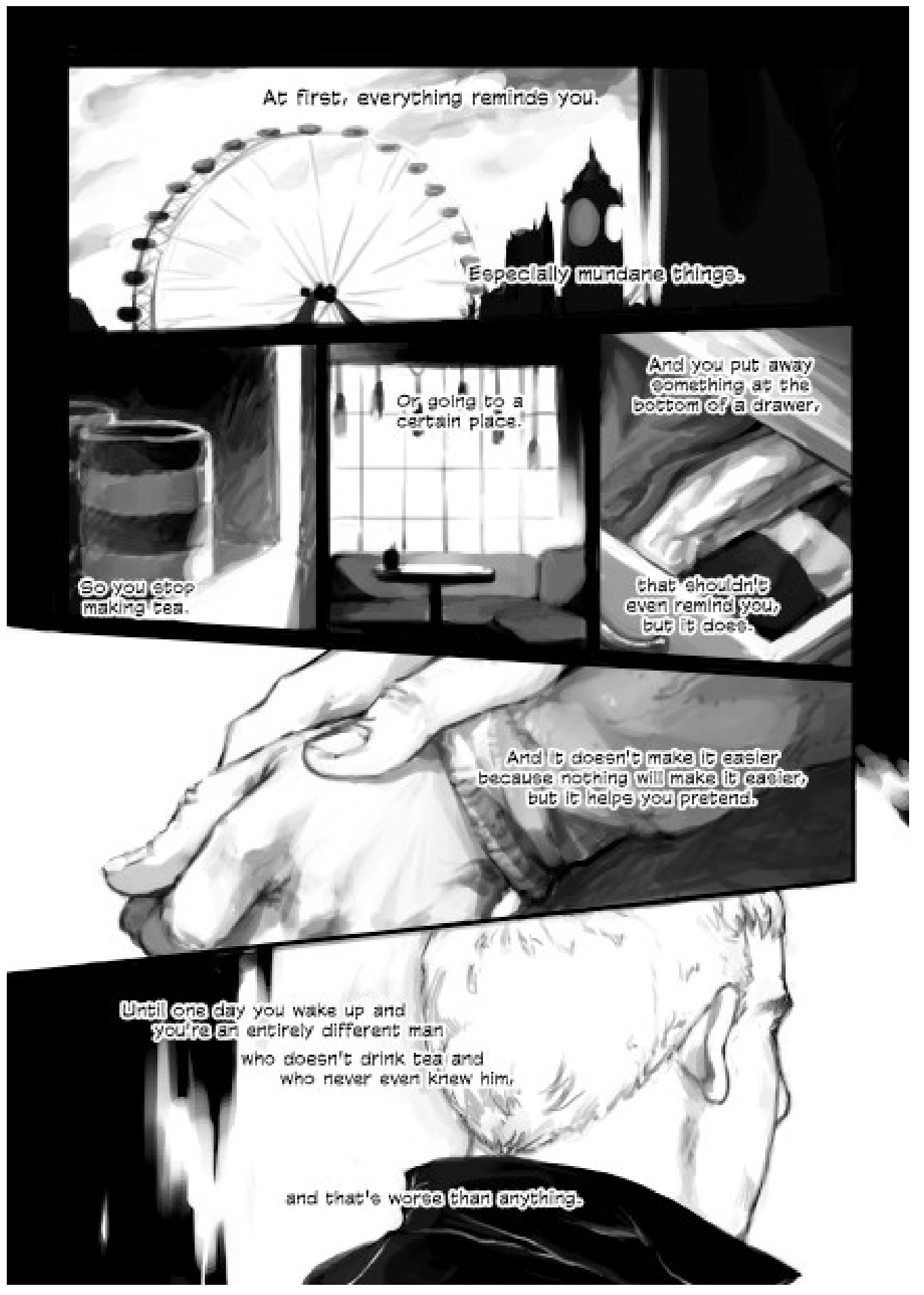

Figura 3. Wreck Fanbook (2012, p. 1) 


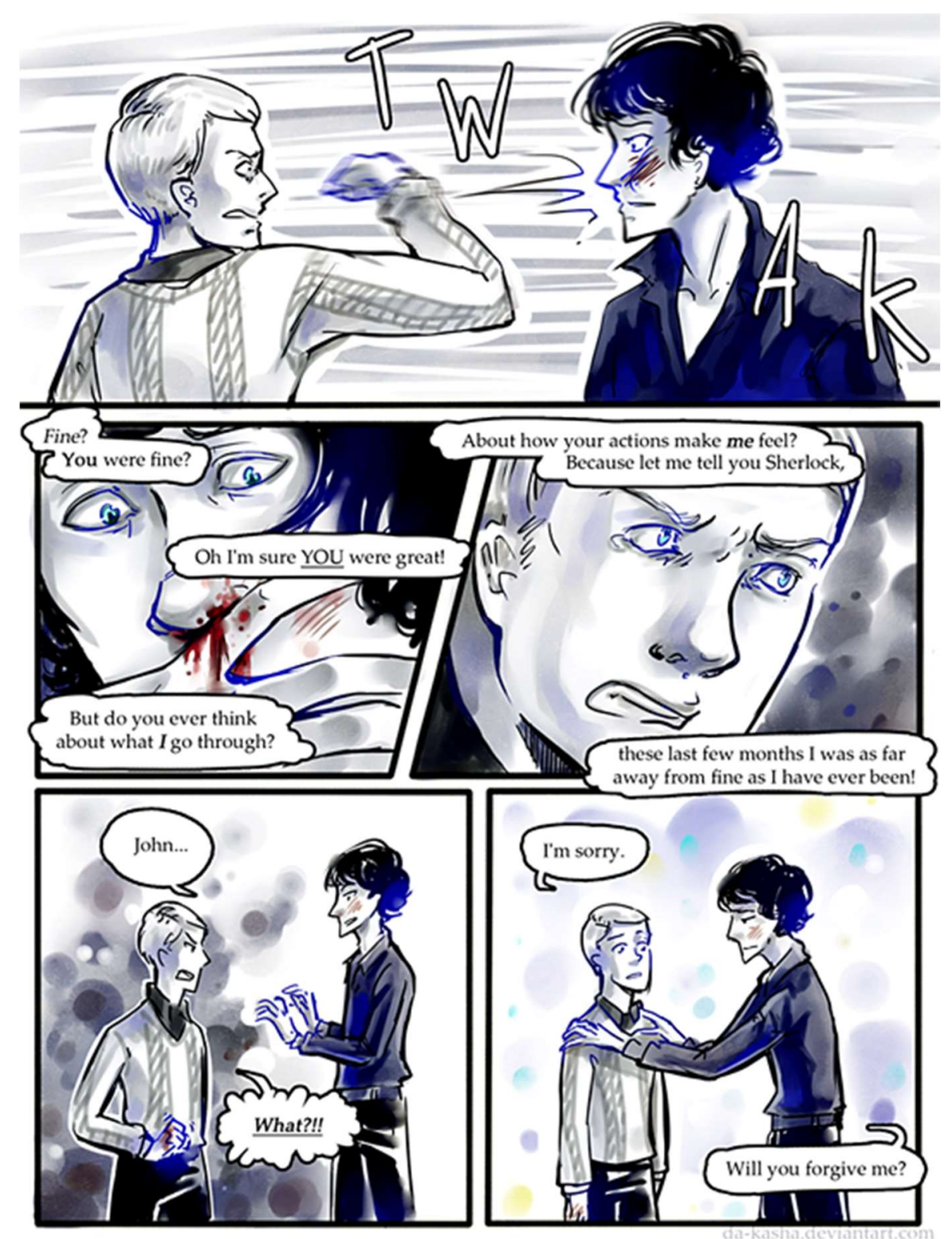

Figura 4. The Reichenbach Resolution (2012, p. 5)

Na Figura 1, intitulada BBC SHERLOCK - Sherlock $(2012)^{3}$, vemos predominantemente a cor azul que ambienta toda a tela, criada em uma simulação de textura de papel. Nela é feita uma pintura digital semelhante à aquarela, a qual escorre pela tela, paralela ao movimento do detetive. As personagens são ali recriadas, dialogicamente ao seriado, porém com determinados traços estilísticos em favor de uma estética própria ao autor. Um deles é a sua feição, com traços simples e olhos grandes, similar à estética japonesa do mangá.

Vemos na imagem uma representação de sua queda em direção à morte, mesmo que falsa, no episódio The Reichenbach Fall (2012), em que Sherlock pula do topo do prédio do Hospital Saint Bart's para enganar e vencer Moriarty em um ato "heroico" de salvação de seus amigos. Além da posição de Sherlock já indicar o movimento de descida,

\footnotetext{
3 Disponível em: <http://arashicat.deviantart.com/art/BBC-SHERLOCK-Sherlock282986332? q=favby\%3ANovaRoris\%2F49425849\&qo=33>. Acesso em: 09 mar. 2016.
} 
de perda da vida, a morte também está representada por uma caveira, presente logo ao lado de Moriarty, seu arqui-inimigo e o motivo de sua queda em primeira instância. Se a queda de Sherlock é em direção à "morte", as pessoas a sua volta representam os seres importantes para si, em uma aproximação aos rostos e memórias que se creem serem vistas no ritual de passagem da vida.

Apontamos um posicionamento do autor desde a escolha das personagens representadas até sua posição em relação a Sherlock na imagem. A opção por representar Molly e Mycroft, por exemplo, em tamanho considerável, sérios e próximos ao rosto de Sherlock, indica sua possível importância, na perspectiva dos fãs, para a resolução do enigma da sobrevivência à queda de Sherlock. Percebemos também a dupla presença de John, primeiramente entregando-lhe uma caneca de chá, como uma lembrança de um momento de rotina pertencente a eles, e, posteriormente, como a última face que Sherlock vê, um rosto composto por um olhar triste e cabisbaixo, pois ele pode ser considerado como aquele que mais sofreria com sua perda. O fato de ser a última personagem representada, além de sua posição, mais próxima a Sherlock, dá indício da proximidade de ambos, tanto internamente ao seriado, quanto representando a importância dada à sua relação pelo autor.

Ao analisarmos a Figura 2, apontamos na fanart uma representação do tema pósmorte - ou pós-Reichenbach, como ficou conhecido pelos fãs -, em que é dada grande ênfase à angústia causada pela falta de Sherlock na vida de John. Aqui, mais abertamente do que na imagem anterior, as questões relativas à morte do detetive ligam-se a um traço emocional, mais do que policial, como sugere o tema do seriado. Esse seria um dos exemplos de divergências na voz social dos fãs, presentes em suas respostas em que se encontra em destaque ora a resolução do enigma da falsa morte do detetive, ora o desvio para o conflito emocional causado por sua perda.

Vemos aqui John, o fiel companheiro do detetive, sentado à mesa da sala de estar no apartamento que dividiam na Baker Street, agora sozinho. A prévia presença física de Sherlock está marcada por elementos que o caracterizam, de maneira a registrar o sentimento de falta causado por sua ausência em John. Assim, na mesa em que está sentado, há uma cadeira vazia em sua frente, o que seria o lugar do detetive. O lugar vazio está, porém, pleno de elementos que o representam, como seu celular, pelo qual realizou o último contato com John (este o segura ligado, como se esperasse o aparelho à sua frente magicamente lhe responder), além do cachecol azul característico do detetive e da caneca de chá. Por fim, ao chão, notamos a representação da sombra do detetive, como se a materialização de sua presença estivesse ali, com John.

Dessa forma, ao mesmo tempo em que ele não está lá, esses elementos metonimicamente o mantém vivo na casa e na vida de John. Essa fanart responde diretamente ao final do episódio The Reichenbach Fall, em que vemos John em frente a uma poltrona vazia, que pertencia a Sherlock, momentos antes da cena do funeral de seu amigo. $\mathrm{O}$ vazio da poltrona no episódio, semelhantemente à cadeira vazia da fanart, ocupa o lugar de sua solidão.

Veremos agora fanarts que assumem o formato de HQ. Para tal, trabalharemos com Wreck Fanbook ${ }^{4}$, de Reapersun, e The Reichenbach Resolution ${ }^{5}$, de Nnaj. Em Wreck

\footnotetext{
${ }^{4}$ Disponível em: <http://reapersun.tumblr.com/tagged/wreck+fanbook/chrono>. Acesso em: 09 mar. 16.

${ }_{5}^{5}$ Disponível em: <http://nnaj.deviantart.com/art/Reichenbach-Resolution-1-of-6-279907966>. Acesso em: 09 mar. 16.
} 
Fanbook, vemos ser deixada de lado a questão da resolução do enigma para dar enfoque à devastação em que se encontra John - wreck, desastre, como sugere o título - após a morte de seu melhor amigo. Além disso, eles imaginam como seria o reencontro dos dois quando Sherlock retornasse dos "mortos", primeiramente com uma discussão e briga física, para depois culminar em uma reconciliação amorosa.

Dentre as escolhas do autor para a representação do tema nessa obra, em uma relação responsiva com o seriado, está primeiramente a opção por uma $\mathrm{HQ}$, uma narrativa em quadrinhos, para o desenrolar da situação emocional de John após a morte do amigo e seu reencontro. Trouxemos como exemplo a imagem que dá abertura à história, presente na Figura 3.

Em um paralelismo criado pelo autor, o quadrinho que inicia a obra traz também como cenário o horizonte da Londres contemporânea, presente na abertura do seriado. Somos iniciados na ambientação da trama, tanto no tempo-espaço, quanto na situação emocional do sujeito que narra a história.

Ao passo em que constatamos, logo no início, a narração de John ao fundo, comentando que tudo o lembra Sherlock, os quadrinhos nos apresentam uma sequência de objetos e locais que estabelecem essa relação para si. Em primeiro lugar, há a caneca, elemento representativo de uma rotina partilhada por ambos e fortemente marcado em todo o enunciado. Há também, no terceiro quadrinho, a reconstrução, com os traços do autor, do restaurante Angelo's, local em que os amigos foram no dia em que se conheceram, em A Study in Pink (2010). Além disso, a imagem da gaveta atuada em conjunto com o texto verbal sobre esconder algo no fundo da gaveta, por um lado, remete à busca por drogas que Sherlock pudesse estar escondendo em seu quarto em $A$ Scandal in Belgravia (2012), mas também remete à prática de esconder-se a si mesmo, como o faz John.

Vemos John em uma situação de negação da morte de Sherlock, ao evitar as coisas que o lembram o amigo: sua casa, amigos em comum, restaurantes frequentados, até hábitos partilhados por eles em sua rotina. Desse modo, John, ao evitar essas lembranças, deixa de ser ele mesmo, pois aquilo que constituía seu outro também fazia parte de si. A partir do momento em que Sherlock não está mais lá, como o mito do andrógeno, John vaga pela cidade de Londres, sem casa fixa, sempre em fuga de suas lembranças, com o desejo de ter sua metade de volta, até que o encontra e somente assim pode voltar a ser o que era, momento representado na HQ quando Sherlock lhe entrega uma caneca de chá. Ele pode voltar a ter seus velhos hábitos, pois ele também está de volta, assim como seu outro.

Em The reichenbach resolution (2012), de Nnaj (Figura 4), apontamos fortemente o viés emocional da morte do detetive. Semelhantemente à obra Wreck Fanbook, essa produção também remete ao encontro de Sherlock e John, desviado para uma questão emocional, porém nesse é apresentado o plano de Sherlock para sua sobrevivência. Apesar de ser um trabalho mais conciso em questão de páginas - somente seis em comparação a 28 do anterior - e possuir um diferente tom-emotivo-volitivo do sujeito na representação da volta de Sherlock, também vemos desenrolar-se uma briga entre os dois, em que John dá um soco no amigo, como um desconto de toda a sua angústia e sofrimento em um Sherlock insolente, preocupado somente em se gabar de seu feito: enganar a Moriarty e a todos com sua falsa morte. No entanto, o embate é sucedido de uma 
reconciliação amigável entre ambos, e não amorosa-erótica, como no final de Wreck Fanbook.

À primeira vista, a seriedade no traço da HQ apresentada anteriormente opõe-se ao estilo "simples" de produção de The reichenbach resolution, em um formato semelhante a um esboço, aliado a um trabalho com as cores azul, preto e vermelho, o que cria um ambiente de cores frias, em contraste com o vermelho do sangue, mesmo que esse não se apresente em sua coloração mais viva. Notamos, porém, que o tom emotivovolitivo do fã faz-se presente ali, como um elemento que caracteriza sua produção. Assim, o produto final com um acabamento relativamente simples no que tange à construção do plano de fundo e das personagens, por exemplo, evidencia uma escolha responsável de um sujeito respondente ao seriado, ali tornado autor.

Alguns elementos destacam-se ao verificarmos as produções supracitadas em sua totalidade. Dentre eles, a recorrência da cor azul, em sua tonalidade fria, que remete à tristeza, a um azul de morte, pois, afinal, esse é o tema das produções, juntamente com o do sofrimento de John. Há também o elemento da caneca de chá, muito forte em Wreck Fanbook, mas também presente nas outras produções apresentadas, como já foi dito acima, por conta de seu elemento de tradição entre os amigos e algo que remete à rotina de ambos, bem como a sua proximidade. Além disso, a questão (homo)afetiva no que tange à relação Sherlock-John é trazida como um elemento forte que repercute grandemente nas construções fanmade, principalmente em fanarts e em fanfics homoeróticas (slash).

Nosso intuito com este trabalho foi o de analisar como os fãs do seriado Sherlock - e, por extensão, fãs de seriado em geral - colocam sua marca em suas produções em uma recepção concebida como produção a partir do desenvolvimento das mídias digitais e da ideologia participativa a ela indissociável.

O estilo marca sua entonação, pois o fã, entendido como sujeito responsivo (e responsável) em relação ao seriado, imprime ali sua voz ao selecionar determinado acabamento ao seu trabalho, seja na escolha da materialidade, dos elementos de produção, ou já na escolha de um tipo enunciativo, sempre, no caso do recorte de nosso objeto, a partir de um viés temático-formal da morte do detetive em The Reichenbach Fall (2012) e sua repercussão emocional.

A construção do enunciado dos fãs como autorais, logo, com marcas estilísticas, conforme expusemos analiticamente dentro de uma breve seleção em nosso trabalho, os coloca em posição de respondentes ativos ao seriado. Nesse processo, o seriado enquanto gênero discursivo assume uma concepção de fã e de público muito mais particip-ativa. $\mathrm{O}$ fã que recebe a produção do seriado também é produtor e não somente receptor de sentidos. Ele ativamente toma a posição de locutor no diálogo e interage com o seriado e, assim, estabelece uma relação de mútua dependência. O fã, tomado enquanto sujeito que assume a posição de autor em sua resposta, é concebido como tal na própria constituição do seriado. Sua recepção participativa na Rede é pretendida e incentivada desde a produção transmidiática dos episódios, em um processo massivo-midiático de autopromoção: fazer circular um produto na Internet é expô-lo na vitrine e incitar discussões a seu respeito é pô-lo em promoção. Eis a receita de sucesso dos seriados a partir das redes sociais.

Desse modo, a recepção ativa do seriado, em especial nas amarras da Rede dentro do que chamamos de contemporaneidade, atua em conjunto com sua produção e constrói, 
em conjunto com renovadas relações entre sujeitos, uma arquitetônica (transmidiaticamente) responsiva do seriado.

\section{Conclusão}

A partir da premissa do diálogo e da unicidade do enunciado enquanto ato irrepetível, procuramos desenvolver, neste trabalho analítico-interpretativo, a ideia dos enunciados dos fãs como autorais. Esses enunciados são responsivos ao seriado, porém, essa característica não só não diminui sua autenticidade, como ainda possibilita a criação de seu estilo, criado nos limites entre o eu e o outro, o fã e o seriado. Para tal, procuramos demonstrar as marcas de subjetividade impressas em sua construção textual, sejam quais forem as materialidades escolhidas, no caso, visuais e verbovisuais.

Nesse sentido, a recepção do seriado também é produção e a própria produção do seriado leva em conta sua recepção por parte dos fãs, na Rede. Procuramos pensar, assim, em um processo dialético-dialógico (PAULA et ali, 2011) de circulação, produção e recepção (trans)midiática do seriado, em uma via de mão dupla entre sua produção e as respostas dos fãs. Ambos, seriado e fã, são interdependentes e levam em consideração um ao outro em sua enunciação, como sujeitos em um diálogo. A própria constituição do gênero depende de sua movimentação na esfera, logo, de sua recepção, de forma que não há seriado sem fã e vice-versa.

Impossível pensarmos o seriado fora de sua circulação na Rede na contemporaneidade. A partir da concepção de que o seriado é um gênero, posto em mobilidade dentro de uma esfera de atividade midiática, procuramos, com este trabalho, dar continuidade aos estudos dos gêneros discursivos em suas dimensões assumidas a partir do apelo participativo das mídias digitais.

\section{REFERÊNCIAS}

BAKHTIN, M. M. Estética da Criação Verbal. Traduzido do russo por Paulo Bezerra. São Paulo: Martins Fontes, 2011.

DISCINI, N. Bakhtin: contribuições para uma estilística discursiva. In: PAULA, L. de; STAFUZZA, G. (Org.). Círculo de Bakhtin: teoria inclassificável. v. 1. Série BakhtinInclassificável. Campinas: Mercado de Letras, 2010.

GRILLO, S. V. De C. "Esfera e campo”. In: BRAIT, B. (Org.). Bakhtin: outros conceitoschave. São Paulo: Contexto, 2006.

JENKINS, H. Textual poachers: television fans and participatory culture. Nova Iorque/Londres: Routledge, 1992.

Convergence culture: where old and new media colide. Nova Iorque: New York University Press, 2006.

LÉVY, P. Cibercultura. São Paulo: Ed. 34, 2008.

MCCLOUD, S. Desvendando os quadrinhos. São Paulo: Makron Books, 1995.

MEDVÍEDEV, P. N. O método formal nos estudos literários. São Paulo: Contexto, 2012. 
MORAES, D. de. O concreto e o virtual: mídia, cultura e tecnologia. Rio de Janeiro: DP\&A editora, 2001.

PAULA, L. et ali. O marxismo no/do Círculo de Bakhtin. Slovo - O Círculo de Bakhtin no contexto dos estudos discursivos. Appris, Curitiba, v. 1, p. 79-98, 2011.

SHERLOCK: $1^{\text {a }}$ Temporada. Direção: Euros Lyn, Paul McGuigan, Toby Haynes. Produção de Mark Gatiss, Steven Moffat. Londres: LOG ON, 2010. 2 DVDs (270 min), widescreen, color. Produzido por BBC (UK). Baseado nas obras de Arthur Conan Doyle.

SHERLOCK: $2^{\circ}$ Temporada. Direção: Euros Lyn, Paul McGuigan, Toby Haynes. Produção de Mark Gatiss, Steven Moffat. Londres: LOG ON, 2012. 2 DVDs (270 min), widescreen, color. Produzido por BBC (UK). Baseado nas obras de Arthur Conan Doyle.

VAUTHIER, B. Auctoridade e tornar-se autor: nas origens da obra do "Círculo B.M.V." (BAKHTIN, MEDVEDEV, VOLOCHINOV). In: PAULA, L. de; STAFUZZA, G. (Org.). Círculo de Bakhtin: teoria inclassificável. v. 1. Série Bakhtin - Inclassificável. Campinas: Mercado de Letras, 2010.

VOLOCHINOV, V. Discurso na vida e discurso na arte (sobre poética sociológica). Tradução de Carlos Alberto Faraco e Cristóvão Tezza. Circulação restrita. [1926]

Recebido em: 18/08/2016

Aprovado em: 20/03/2017 